ppi $201502 Z U 4645$

Esta publicación científica en formato digital es continuidad de la revista impresa ISSN-Versión Impresa 0798-1406 / ISSN-Versión on line 2542-3185Depósito legal pp $197402 Z$ U34
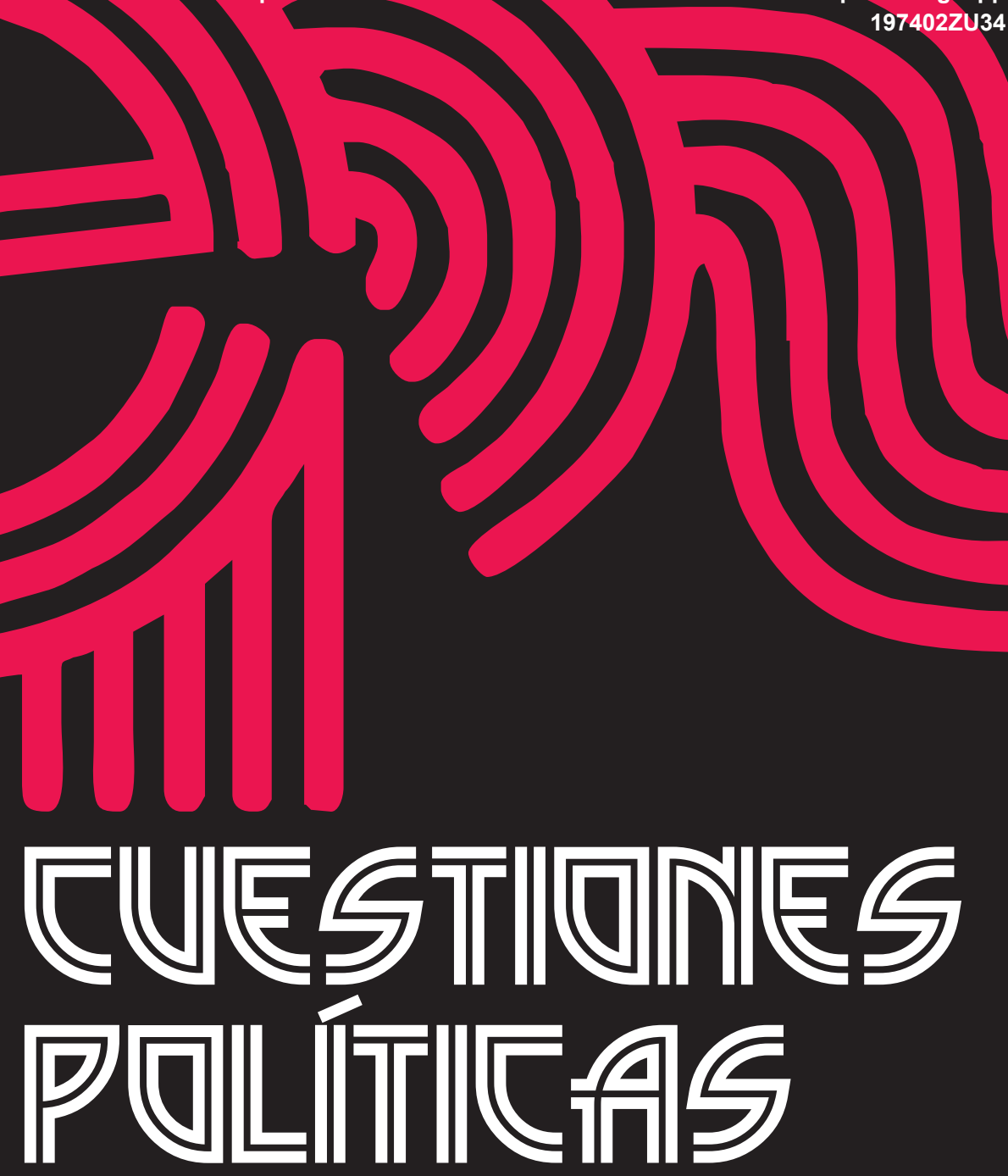

Instituto de Estudios Políticos y Derecho Público "Dr. Humberto J. La Roche" de la Facultad de Ciencias Jurídicas y Políticas de la Universidad del Zulia Maracaibo, Venezuela
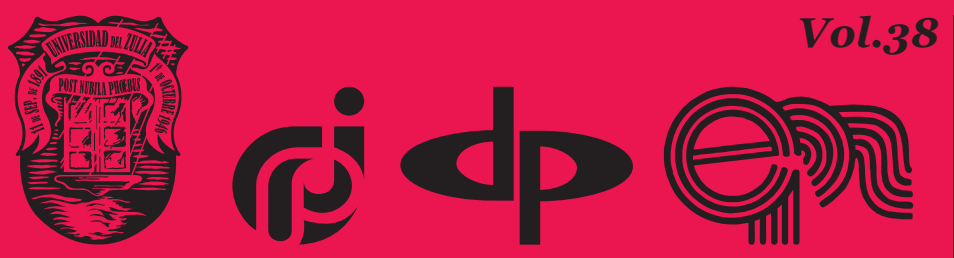

$N^{\circ}$ Especial 2da Parte 2020 


\title{
Mediation in criminal proceedings: legal regulation in Ukraine and foreign experience of application
}

\author{
DOI: https://doi.org/10.46398/cuestpol.382e.32
}

\author{
Motliakh Oleksandr * \\ Bezusyi Vadym ** \\ Chudnovskyi Oleksandr *** \\ Burlakov Serhii **** \\ Shevchuk Hennadii
}

\section{Abstract}

The purpose of the article is to study those conceived of the use of the mediation institution in the criminal proceedings of European countries to implement positive experience in Ukrainian law. The theme of the study is the institution of mediation in criminal proceedings. The following scientific methods were used in the research: dialectical, formal and logical, and legal, system and functional, comparative and legal, legal and other modeled methods. We study the concetorities of the regulation and legal of mediation in criminal proceedings in Ukraine, as well as the practice of its implementation, which is more than modest with other European states. Therefore, we draw on the experience of countries such as Germany, Poland, and the United Kingdom. It is concluded that, given the successful functioning of the mediation institution in most countries, we propose to emulate this positive practice and a separate law "On Mediation" in Ukraine. It is established that the main right for the legislative registration of mediation in Ukraine is the lack of information on the existence of such a way of resolving a criminal case.

* Doctor of Law, Professor, Head of the Scientific Laboratory for Psychological Support and Psychophysiological Research of the Educational and Scientific Institute of Correspondence and Distance Learning of the National Academy of Internal Affairs. ORCID ID: https://orcid.org/oooo-0003-29667506. Email: nnizn@naiau.kiev.ua

** Doctor of Law, Associate Professor, Professor of the Department of Legal Support of Economic Activity of Faculty № 6 of Kharkiv National University of Internal Affairs. ORCID ID: https://orcid.org/ooooooo3-4209-5709. E-mail: odin.univd@gmail.com

** PhD in Law, Associate Professor, Associate Professor of the Department of General Legal Disciplines of Dnipropetrovsk State University of Internal Affairs. ORCID ID: https://orcid.org/oooo-0002-22541292. Email: mail@dduvs.in.ua

****Doctor of Law, Leading Researcher at the Research Institute of Public Law. ORCID ID: https://orcid. org/oooo-ooo1-8254-2724. Email: sipl1@ukr.net

*****PhD in Law, Associate Professor, Associate Professor of Police Law Department of the National Academy of Internal Affairs. ORCID ID: https://orcid.org/oooo-0002-9328-1977. Email: koo5@ naiau.kiev.ua 
Keywords: mediation in criminal proceedings; restorative justice; legislative regulation; european mediation experience; comparative law.

\section{Mediación en procesos penales: regulación legal en Ucrania y experiencia de aplicación extranjera}

\section{Resumen}

El propósito del artículo es estudiar las peculiaridades del uso de la institución de mediación en los procesos penales de los países europeos para implementar esta experiencia positiva en la legislación de Ucrania. El tema del estudio es la institución de la mediación en los procesos penales. En la investigación se utilizaron los siguientes métodos científicos: método dialéctico, formal y lógico, histórico y legal, sistema y funcional, comparativo y legal, modelado legal y otros métodos. Se estudian las peculiaridades de la regulación normativa y legal de la mediación en los procesos penales en Ucrania, así como la práctica de su aplicación (que es más que modesta en comparación con otros Estados europeos). Por lo tanto, recurrimos a la experiencia de países como Alemania, Polonia y el Reino Unido. Se concluye que, dado el funcionamiento exitoso de la institución de la mediación en la mayoría de los países, proponemos emular esta práctica positiva y aprobar una ley separada «Sobre Mediación» en Ucrania. Se establece que el principal obstáculo para el registro legislativo de la mediación en Ucrania es la falta de información sobre la existencia de tal forma de resolver un caso penal.

Palabras clave: mediación en el proceso penal; justicia restaurativa; regulación legislativa; experiencia europea de mediación; derecho comparado.

\section{Introduction}

The institution of mediation has become widely used in the settlement of conflicts (disputes) in the world and European practice, which provides an opportunity to choose pre-trial and extrajudicial methods for resolving conflicts (disputes) while maintaining the ability to go to court.

Thus, on 21 May 2008, the European Union adopted Directive 2008/52 / EC (the European Parliament and the Council of the European Union 2008), which is aimed to facilitate access to alternative dispute resolution 
Motliakh. Oleksandr, Bezusyi Vadym, Chudnovskyi Oleksandr, Burlakov Serhii y Shevchuk Hennadii

and to promote peaceful settlement of disputes by encouraging the use of mediation and ensuring a balanced relationship between mediation and the judiciary proceedings.

Par. 8 of the Preamble to Directive 2008/52 / EC states that the provisions of this Directive will apply only to mediation in international disputes, but nothing should prevent Member States from applying these provisions in internal mediation processes as well.

Ukraine is also a signatory to the United Nations Convention on International Settlement Agreements Resulting from Mediation (United Nations Commission on International Trade Law 2019). In order to ratify and implement this Convention, Ukraine needs to adopt a special law that will define the main provisions, in particular, on the scope of mediation, the procedure for its implementation and the status of mediators.

Besides, Art. 124 of the Constitution of Ukraine (Law of Ukraine 1996) stipulates that the law may determine the mandatory pre-trial procedure for dispute resolution.

Currently, the legislation of Ukraine does not regulate the mediation procedure, but the practice of resolving conflicts (disputes) through mediation is gradually increasing. Thus, the purpose of the article is to study the peculiarities of the use of the institution of mediation in criminal proceedings of the European countries in order to implement the positive experience in the legislation of Ukraine and to adopt a separate law "On Mediation".

\section{Materials and methods}

The methodological basis for the study is the system of general and specific scientific methods and approaches that provide an objective analysis of the subject. Taking into account the specifics of the topic, purpose and objectives of the study, the following methods were used:

Dialectical method was applied to clarify and supplement the existing theoretical views on the problem with new arguments.

Formal and logical method allowed to clarify the content of key concepts and definitions used in the article, and to formulate the authors' approaches to these issues.

Historical and legal method was helpful in the study of the concept, essence and content of restorative justice, the conceptual foundations of restorative justice and the genesis of the institution of mediation in the criminal procedure legislation of Ukraine. 
System and functional method, as well as comparative and legal method were used in the study of conceptual foundations of the institution of mediation in the criminal law of foreign countries. Legal modeling method was applied in determining the ways of introducing the institution of mediation in the criminal procedure of Ukraine.

\section{Theoretical bases of the investigation}

The theoretical basis for the study is the works of foreign and Ukrainian scientists, who studied the issue under consideration. For example, the concept of mediation was provided by Kohan (2014). Vinogradova (2003) claims that the main advantage of mediation in criminal proceedings is providing the opportunity both for a victim and an offender to participate in resolving the conflict and discussing the conditions for remedying.

Zhmud (2008) investigated the process of implementation of the institution of mediation in criminal proceedings in Ukraine, while the number of other researchers studied the efficiency of mediation procedure in other countries. Thus, Zemlianska (2008) examined the effectiveness of this form of restorative justice in Poland; Trenczek (2001) paid attention to the legislation regulating the application of mediation procedures in Germany; Gailly (2003), Golovko (2003) considered the types of mediation procedure in the UK.

A number of international, European and domestic legal acts, regulating the issue under consideration, such as: Recommendation No. R (99) 19 of the Committee of Ministers to member States concerning mediation in penal matters; Framework Decision on the standing of victims in criminal proceedings; Directive 2008/52/EC on certain aspects of mediation in civil and commercial matters; Criminal Codes and Codes of Criminal Procedure of Ukraine, Germany, Poland, etc. are the basis for the research as well.

\section{Results and Discussions}

For the beginning it is necessary to note that the position on the importance of adopting a separate law "On Mediation" is supported by a significant number of researchers. Firstly, this institution has proven its effectiveness in solving criminal cases in many countries around the world. Secondly, it is necessary to bring the legislation of our country in line with European standards in connection with the integration of Ukraine into the European Community. A number of recommendations and decisions of the 
Motliakh. Oleksandr, Bezusyi Vadym, Chudnovskyi Oleksandr, Burlakov Serhii y Shevchuk Hennadii

Council of Europe are addressed on the issue of conciliation procedures, in particular: Recommendation № R (99) 19 “On Mediation in Criminal Matters" (Committee of Ministers of the Council of Europe 1999), which considers the use of mediation in criminal matters as a flexible, comprehensive, problem-solving, participatory option complementary or alternative to traditional criminal proceedings; Recommendation Rec (2003)20 of the Committee of Ministers to member states concerning new ways of dealing with juvenile delinquency and the role of juvenile justice (Committee of Ministers of the Council of Europe 2003); Council Framework Decision on the standing of victims in criminal proceedings (Committee of Ministers of the Council of Europe 2001), etc.

The institution of mediation emerged in criminal cases in the late $20^{\text {th }}$ century in contrast to the traditional judicial system of conflict resolution and was associated with the change of the main parties to the criminal procedure. In particular, the State and the offender were replaced by the victim and the offender. The purpose of mediation was to provide new parties with the opportunity to find a way to resolve the conflict on mutually beneficial terms. They were given an active role in the criminal procedure, as they became active participants in the mediation process, and any decision required their mutual consent.

The victim was given an opportunity to get an apology and explanation from the offender, to discuss acceptable conditions for atonement. The offender was given the opportunity to meet with the victim, to empathize with his (her) status of victim of crime, to explain his (her) behavior, to apologize, to participate in resolving the conflict and discussing the conditions for remedying (Vinogradova 2003).

The term "mediation" comes from the Latin word "тесіiаге", which means "to be a mediator". Thus, mediation is a specific form of regulation of disputes, conflicts, coordination of interests.

According to the Recommendations № R (99) mediation means any process whereby the victim and the offender are enabled, if they freely consent, to participate actively in the resolution of matters arising from the crime through the help of an impartial third party (mediator).

Based on the Council Framework Decision on the standing of victims in criminal proceedings "mediation in criminal cases" shall be understood as the search, prior to or during criminal proceedings, for a negotiated solution between the victim and the author of the offence, mediated by a competent person.

Mediation, from a scientific perspective, is a type of alternative dispute resolution, a method of resolving disputes involving a mediator, who helps the parties to the conflict to establish communication and to analyze the conflict situation so that they can choose the solution that would satisfy the 
interests and the needs of all parties to the conflict. Unlike formal judicial or arbitral proceedings, the parties reach an agreement by themselves during mediation process - mediator does not make decisions for them (Kohan 2014).

The main principles of mediation in criminal proceedings are the following:

- mediation should take place only when all parties have voluntarily agreed on this. The parties can also withdraw their consent at any stage of the mediation;

- any discussions during the meeting are confidential and may not be used in the future, unless the parties agree;

- mediation in criminal cases should be an available mean;

- mediation in criminal cases should be admissible at any stage of proceedings;

- mediation is independent and autonomous within the criminal justice system.

The possibility of using mediation in resolving criminal cases in Ukraine is provided in Art. 46 of the Criminal Code (Law of Ukraine 2001), according to which person who has committed a minor criminal offense or medium grave reckless offense (except corruption offenses) for the first time shall be exempt from criminal liability if he/she reconciled with the victim and compensated the losses or repaired the damage inflicted. In addition, Chapter 35 of the Code of Criminal Procedure of Ukraine (Law of Ukraine 2012) is devoted to criminal proceedings on the basis of agreements, which, in particular, describes the procedure for concluding a conciliation agreement between the victim and suspect or accused in detail, namely: the process of initiating and concluding such an agreement; consequences of concluding and approving the agreement, general procedure of court proceedings on the basis of the agreement, consequences of non-fulfillment of the agreement.

Besides, there are a number of other legal acts in Ukraine concerning the application of mediation procedure in criminal proceedings. In particular, paragraph 21 of the Resolution of the Plenum of the Supreme Court of Ukraine "On the Practice of Applying Legislation on Juvenile Crimes by Courts of Ukraine" (Plenum of the Supreme Court of Ukraine 2004) recommends courts to support the activities of those public organizations that aim to achieve reconciliation between the juvenile, who committed the crime, and the victim: to provide relevant information to such organizations, to inform defendants of the existence of such organizations and to provide the former with the opportunity to contact these organizations to resolve the conflict and achieve reconciliation. 
Motliakh. Oleksandr, Bezusyi Vadym, Chudnovskyi Oleksandr, Burlakov Serhii y Shevchuk Hennadii

Mediation in criminal proceedings: legal regulation in Ukraine and foreign experience of application

The letter of then Prosecutor General of Ukraine O. Medvedko (2008) drew attention of regional prosecutors to the need to provide victims and defendants with the information about their right to reconciliation on their own or through mediators and the possible consequences of such reconciliation.

Despite the absence of a separate law on mediation, Ukraine can still boast of its own experience in the application of mediation procedure, which confirms the high efficiency of the use of this institution in resolving conflicts. Thus, since 2003, experiments have been actively conducted in courts (in particular, in the cities of Kyiv, Kharkiv, Ivano-Frankivsk, the Autonomous Republic of Crimea and others). There are also a number of Regional Mediation Groups in Ukraine, which have merged into the Association of Mediation Groups of Ukraine and the Ukrainian Center for Understanding, which is actively involved in the implementation of reconciliation programs for victims and offenders and educational activities in this area. Ukrainian Center for Understanding conducted an interim evaluation of the implementation of restorative justice programs in 10 regions of Ukraine for the period of September 2006 to February 2007. 41 restorative justice programs were conducted during the reporting period, including 39 mediation procedures in criminal cases (Zhmud 2008, p. 13).

However, this practice of using this institution in Ukraine is more than modest compared to other European (and not only) countries.

For example, mediation is the main form of restorative justice in Poland. This State is one of the first countries in Eastern Europe, in which restorative justice was introduced (in the mid-1990s). In 1995, the Patronage Penitentiary Association, in particular its Mediation Implementation Group, initiated a three-year pilot project on mediation between victims and offenders for juvenile offenders. After evaluating the results of the project, this organization along with the Ministry of Justice, developed proposals for the institutionalization of the mediation system in Polish criminal justice. In fact, in 2000, the Implementation Group was transformed into an independent non-governmental association - the Polish Mediation Center (PCM). Mediation was formally introduced into the Polish criminal system in 1997. Mediation was conducted only at the stage of preparatory court proceedings during the first years. Just 18 cases were referred to mediation in 1998, but in 2000 there were already 722138 of such cases (Zemlianska 2008, pp. 85-87).

In 2000, the PMC initiated amendments to the Polish criminal procedure legislation, which resulted in the amendment to the Art. 23a entitled "Mediation Procedure" of the Code of Criminal Procedure of Poland (Law of the Republic of Poland 1997). This article enshrines that the Court or legal Secretary Court, and in preparatory proceedings the public prosecutor or other body conducting the proceedings may, at the initiative 
of or with the consent of the accused and the victim take the matter to the institution or persons empowered to carry out mediation between the victim and the accused, and their teaching, informing about the purposes and the principles of mediation. The participation of the defendant and the victim in the mediation proceedings is voluntary. The consent to participate in mediation proceedings is accepted by the body that refers the case to mediation, or by the mediator after explaining to the defendant and the victim the purposes and rules of mediation proceedings. The defendant (accused) and the victim are also explained the right to refuse mediation until the end of the mediation proceedings.

The rule that limits the duration of the mediation procedure to one month is extremely effective. This allows to prevent abuse and delay of mediation proceedings, as well as to ensure its timeliness. It should be noted that this term is not taken into account during the pre-trial investigation.

In order to concretize the above article and to implement it effectively the Order "On the procedure for mediation in criminal cases" was issued on June 13, 2003 (Czarnecka-Dzialuk 2005, p. 142). While the Code of Criminal Procedure of Poland enshrines general procedure for the mediation procedure, the Order establishes the peculiarities of its implementation, in particular: the conditions to be met by institutions and persons entitled to conduct a mediation procedure; the procedure for the appointment and removal of institutions and persons endowed with the right to conduct a mediation procedure; the scope and conditions of providing case materials to institutions and persons entitled to conduct a mediation procedure; method and procedure for conducting mediation.

Unlike in most countries, mediation in Germany is mainly used in criminal rather than in civil proceedings. This procedure is used, in particular, in the framework of the 'Täter-Opfer-Ausgleich' programs, which is translated as 'Offender-Victim-Balancing' or 'victim-offender mediation' (VOM); it means both conflict settlement and reconciliation. TOAprograms are quite similar to Victim-Offender Mediation Programming (VOMP) in Australia or the United States in their approach and procedure. There are currently about 400 programs operating in Germany nowadays, mostly community based and / or state financed; about $2 / 3$ operate within the juvenile justice context and $1 / 3$ of the programs work also with adult offenders. Both get most of their cases referred through the prosecutor's office. However, several programs accept self-initiated cases directly from victims or offenders (Trenczek 2001, pp. 2 - 3).

As for the legislative consolidation of the application of mediation procedures, it was envisaged in the Law on Juvenile Justice of 1953. In 1990, the legislator strengthened the influence of mediation by amending the above law and since then judges of juvenile courts and prosecutors have been given the right to formally refer cases to mediation and to dismiss 
Motliakh. Oleksandr, Bezusyi Vadym, Chudnovskyi Oleksandr, Burlakov Serhii y Shevchuk Hennadii

Mediation in criminal proceedings: legal regulation in Ukraine and foreign experience of application

criminal cases in case of successful completion of mediation (The European Forum for Victim-Offender Mediation and Restorative Justice 2000, p. 257). Mediation has been defined in the Law on Juvenile Justice as a judicial measure since 1991.

The procedure for mediation between an adult offender and a victim is established by Articles 153 and 153a of the Criminal Procedure Code of Germany (Law of the Federal Republic of Germany 2012). According to the provisions of these articles, in order to be able to use mediation, an offense committed by an adult must be of minor offence or medium gravity (cases in which the penalty may be a fine or imprisonment from 1 month to 5 years). In cases of committing a crime of minor gravity, the prosecutor has the right to dismiss the case independently if the offender has compensated the victim or reached reconciliation as a result of mediation. In cases of a more serious crime, the court may dismiss the criminal case at the request of the prosecutor, if both damages and reconciliation have been reached during mediation.

Article 46a of the Criminal Code of Germany (Law of the Federal Republic of Germany 1998) regulates sentencing and provides for two possibilities for mediation. Thus, if the offender 1) in an effort to achieve reconciliation with the victim, has made full restitution or the major part thereof for his offense, or has earnestly tried to make restitution; or 2) in a case in which making restitution for the harm caused required substantial personal services or personal sacrifice on his part, has made full compensation or the major part thereof to the victim, the court may mitigate the sentence pursuant to section 49 (1) or, unless the sentence to be imposed on the offender is imprisonment of more than one year or a fine of more than three hundred and sixty daily units, may order a discharge.

The Mediation Act was adopted in 2012 in order to facilitate out-ofcourt dispute resolution procedures in Germany (the Mediation Act of 21 July 2012). The Act does not clearly define its scope, so it can be applied in various areas of law, including criminal law.

The Act consists of 9 paragraphs and provides definitions of "mediation" and "mediator", as well as establishes general principles of the mediation procedure, such as: the task of the mediator, the obligation to disclose information, the circumstances under which the mediator cannot participate in procedures, the rule of confidentiality, the obligation to ensure training and retraining as a mediator, etc.

In terms of statistics, the total number of cases referred to mediation (for adults and juvenile offenders) increased from 2,100 in 1989 to 9,100 in 1995 . About 20,000 cases are currently referred to mediation per year. 
A similar process can be observed with regard to VOM programs. Most institutions supporting victim-offender mediation deal with fewer than 50 cases a year. The biggest program is the Waage in Hannover which handles about 440 cases a year, involving about 500 offenders and even more victims. Until 1995, the roughly 400 VOM programs that were registered at the national VOM service bureau dealt with a total of about 9,00o cases a year (Trenczek 2001, p. 5).

The institution of mediation in criminal proceedings in the UK began to be actively used in the 80's of the last century. Until recently, there was no special legislation on restorative justice in the UK (as in many other European countries). The situation changed with the adoption of the Youth Justice and Criminal Evidence Act (enacted in 1999). The Youth Justice and Criminal Evidence Act introduces a mandatory sentence, the Referral Order, for young offenders appearing in court for the first time who have not committed an offence likely to result in custody. The young person is referred to a Youth Offender Panel which will work out the content of the order. This YOP can include: the offender, his immediate family or carers, other supporters of the offender, the victim(s) and their suppporters and three members of the community. The purpose of this meeting is to facilitate a frank discussion about what occurred, how people have been affected, and what needs to occur to make amends, and to prevent any further offending. All this sounds more like Family Group Conferencing, and it has been described by the government as the first introduction of restorative justice into the Court itself (Gailly 2003).

Two types of mediation in the UK can be distinguished depending on the stage of criminal proceedings: police mediation and judicial mediation. The essence of police mediation is that before deciding to prosecute, the police may refer the case to the mediation service, which usually consists of the members of the probation service, representatives of relevant public organizations, and sometimes of the police officers. The Mediation Service organizes and conducts a conciliation procedure, which means a meeting of the mediator with the parties to the conflict to find a compromise. A joint meeting is not obligatory and can take place subject to a preliminary agreement on compensation to the victim, which lies in the payment of a sum of money, written or oral apologies, public works, etc.

In the case of successful mediation, namely the conclusion of an agreement between the parties, the police refrain from criminal prosecution, limiting themselves to the simple warning in formal or informal form. If the person does not comply with the terms of the agreement, then the victim may be provided with legal assistance to file claims in civil proceedings.

The specific conditions for the use of police mediation have their nuances in different counties. In particular, in Northamptonshire, where mediation is handled by a special bureau for adults (adult reparation bureau), 
Motliakh. Oleksandr, Bezusyi Vadym, Chudnovskyi Oleksandr, Burlakov Serhii y Shevchuk Hennadii

mediation depends on the assessment of five criteria (Golovko 2003, p. 72): 1) the nature and gravity of the criminal act; the presence of public interest in the case; 2) the presence of a sufficient evidence to convict a person if the case will be considered in court; 3 ) recognition of all the circumstances of the case by the person, including his (her) guilt; 4) the needs of the victim.

Judicial mediation (the experience of Coventry, Leeds) is applicable to all categories of criminal cases. It is closely connected with the English procedural feature, namely the possibility for the court to postpone the pronouncement of the final verdict. That is, there is usually a fairly long period of time (within two months) between the consideration of the issue of guilt and the issue of punishment, the purpose of which is to collect information about the personality of the perpetrator, as well as the solution of some other procedural tasks. The competent non-governmental organization tries to act as a mediator between the victim and the convict during this period, convincing the latter of the need to voluntarily compensate for the damage caused by the crime. In the case of successful mediation, signing and execution of the relevant agreement, the judge almost always takes into account a similar circumstance in determining the extent and amount of punishment (Golovko 2003, p. 73).

Public organizations are actively involved in the mediation procedure. Thus, there is no specially authorized body for mediation in the UK. The main organization that provides mediation services is the national organization Mediation UK, which conducts training, accreditation for mediators, coordination, and management of mediation activities. Mediators are divided into professionals who work on a permanent basis and volunteers who conduct mediation free of charge in their free time. Restorative Justice Consortium is in the second place. The Thames Valley project, which was launched in 1998 and dealt at first with juvenile delinquency and later with all categories of offenders, also deserves attention. The training of mediators lies in basic training in reconciliation programs conducted by independent trainers or police officers (Nestor 2014, p. 147)

It should be noted that the use of mediation is carried out for the purpose of: meeting the needs of the victim; providing compensation to the victim; reintegration of offenders into their communities; prevention and / or reduction of the risk of further crime; reducing the possibility of future conflicts between victims and perpetrators; meeting the needs of perpetrators; involvement of the family; involvement of the community; ensuring a fair response to the crime (Shapland et al. 2004).

The introduction of mediation in the UK criminal process is well accepted by scholars, as the State's efforts are aimed at making the main function of criminal justice compensatory rather than punitive. 


\section{Conclusion}

Thus, mediation is a technique for the resolution of conflicts, which proved its considerable efficiency (Sufiyarova \& Mansurov 2018, p. 206). It has a new approach to crime, punishment, victim, offender, and seeks to repair damaged relationships between victim, offender and society. In this approach, all parties involved in a criminal act come together to discuss the consequences of crime and interact with each other to deal with the consequences of a crime (Ghasemi et al, 2018).

The introduction of the institution of mediation in the criminal procedure legislation of Ukraine took place in 2012 with the adoption of the new Code of Criminal Procedure of Ukraine, which provides for the possibility of concluding a conciliation agreement between victim and suspected or accused. However, today there are a number of unresolved issues of organizational and procedural nature of the application of mediation procedure in the criminal procedural law of Ukraine, as this institution is used mainly in civil proceedings. That is why some scholars stress on the impossibility of using civil law models for the analysis of modern criminal procedural phenomena (Karnozova 2013, p. 176). The opponents of mediation in criminal proceedings often consider mediation process as a kind of forgiveness, impunity for the perpetrator by the State. The supporters of this institution state that such an approach is largely based on a misunderstanding of the very essence of the institution of mediation (Markovicheva 2009).

At the same time, the experience of many European countries demonstrates that mediation is an effective tool for resolving criminal cases and one of the methods of relieving the judiciary. The institution of mediation has been operating successfully for over 25 years in most countries, including Austria, Belgium, Great Britain, Norway, Germany, Finland, Poland, the United States, Australia, New Zealand, etc. Using the experience of foreign States, in which mediation procedure has been applied for a long time, is of great theoretical and practical importance for our country. It is clear that not all provisions that are effectively implemented in the practice of applying the institution of mediation in foreign countries can be taken into account and used in Ukraine. After all, economic, political, socio-cultural situation of each State contributes strongly to this issue.

The proposals to adopt the law "On Mediation", to introduce the mediator to the range of parties to criminal procedure, to determine his (her) rights and responsibilities, to develop organizational and logistical measures to ensure the activities of mediators (Tumaniants 2009, p. 140) are more than relevant. The main obstacle to the legalization of mediation in Ukraine, in our opinion, is the lack of information about the possibility of 
Motliakh. Oleksandr, Bezusyi Vadym, Chudnovskyi Oleksandr, Burlakov Serhii y Shevchuk Hennadii

such a way of resolving a criminal case, because the parties are usually not familiar with the procedure for concluding a conciliation agreement and the consequences of its conclusion and approval.

\section{Bibliographic References}

CZARNECKA-DZIALUKC, Beata. 2005. "Victim-Offender Mediation with Juveniles in Poland. Victim-Offender Mediation with Youth Offenders in Europe: An Overview and Comparison of 15 Countries". Springer. Netherlands, Dordrecht. pp. 137-156.

COMMITTEE OF MINISTERS OF THE COUNCIL OF EUROPE. 1999. Recommendation No. R (99) 19 of the Committee of Ministers to member States concerning mediation in penal matters (Adopted by the Committee of Ministers on 15 September 1999 at the 679th meeting of the Ministers' Deputies).

COMMITTEE OF MINISTERS OF THE COUNCIL OF EUROPE. 2001. Council Framework Decision on the standing of victims in criminal proceedings of 15 March 2001 (2001/220/JHA). In: EUR-Lex. Available online. In: Available online. https://eur-lex.europa.eu/legal-content/EN/ TXT/?uri=celex\%3A32001Fo220. Date of consultation: 18/09/2020.

COMMITTEE OF MINISTERS OF THE COUNCIL OF EUROPE. 2003. Recommendation Rec (2003) 20 of the Committee of Ministers to member states concerning new ways of dealing with juvenile delinquency and the role of juvenile justice (Adopted by the Committee of Ministers on 24 September 2003 at the 853rd meeting of the Ministers' Deputies). Available online. In: https://pjp-eu.coe.int/ documents/41781569/42171329/CMRec+\%282003\%29+20+concer ning+new+ways + of + dealing +with + juvenile+delinquency + and + the $+r$ ole+of+juvenile+justice.pdf/eg6fogbf-325d-4ed5-ao7f-f4c3f663be54. Date of consultation: 18/09/2020.

GAILLY, Philippe. 2003. Restorative Justice in England and Wales. In: Actions Réparatrices Prestations Et Guidances Educatives (ARPEGE). Liège, Belgium. Available online. In: http://www.arpegeasbl.be/site/FCK STOCK/File/Restaurative\%20Justice\%20in\%20England\%20and\%20 Wales.pdf. Date of consultation: 18/09/2020.

GHASEMI, Abbas, SHEIDAEIAN, Mehdi, MIRKHALILI, Seyed and DARABI, Shahrdad. 2018. "The challenges of restorative justice and executive strategies in Iran's penal system abstract" In: Amazonia Investiga, Vol. 7, No. 14, 170-178. 
GOLOVKO, Leonid. 2003. Alternatives to criminal prosecution as a form of procedural differentiation (modern development trends). Doctoral Dissertation. Lomonosov Moscow State University.

KARNOZOVA, Liudmyla. 2013. "Mediation as a way to respond to acts prohibited by criminal law" In: Bulletin of Volgograd State University. Vol 3, No. 20, pp. 151- 174.

KOHAN, Hanna. 2014. "Does Ukraine need mediation?” In: Legal Adviser, Issue 2, Num. 74. Available online. In: http://yurradnik.com.ua/stati/ d1-87-do-b8-do-bf-do-be-d1-82-d1-8o-d1-96-do-b1-do-bd-do-bo-dobc-do-b5-do-b4-d1-96-do-bo-d1-86-d1-96-d1-8f-d1-83-do-ba-d1-8odo-bo-d1-97-do-bd-d1-96/ Date of consultation: 18/09/2020.

LAW OF THE FEDERAL REPUBLIC OF GERMANY. 1987. Code of Criminal Procedure as published on 7 April 1987, as last amended by Article 3 of the Act of 11 July 2019. Available online. In: https://www.gesetze-iminternet.de/englisch_stpo/englisch_stpo.html. Date of consultation: 18/09/2020.

LAW OF THE FEDERAL REPUBLIC OF GERMANY. 1998. Criminal Code in the version promulgated on 13 November 1998, last amended by Article 1 of the Law of 24 September 2013, and with the text of Article 6(18) of the Law of 10 October 2013. Available online. In: https://www. legislationline.org/download/id/6115/file/Germany_CC_am2013_ en.pdf. Date of consultation: 18/09/2020.

LAW OF THE FEDERAL REPUBLIC OF GERMANY. 2012. Mediation Act of 21 July 2012, as last amended by Article 135 of the Statutory Instrument of 31 August 2015. Available online. In: https://www.gesetze-iminternet.de/englisch_mediationsg/englisch_mediationsg.html. Date of consultation: $18 / 09 / 2020$.

LAW OF THE REPUBLIC OF POLAND. 1997. The Code of Criminal Procedure of June 06, 1997. Available online. In: https://www.global-regulation. $\mathrm{com} /$ translation/poland/7050083/the-act-of-6-june-1997.-the-codeof-criminal-procedure.html. Date of consultation: 18/09/2020.

LAW OF UKRAINE. 2001. Criminal Code of Ukraine of April 05, 2001 no. 2341-III. Available online. In: https://zakon.rada.gov.ua/laws/ show/2341-14\#Text. Date of consultation: 18/09/2020.

LAW OF UKRAINE. 1996. The Constitution of Ukraine of June 28, 1996 no. 254k/96-VR. Available online. In: http://search.ligazakon.ua/1_doc2. nsf/link1/Z960254K.html. Date of consultation: 18/09/2020. 
Motliakh. Oleksandr, Bezusyi Vadym, Chudnovskyi Oleksandr, Burlakov Serhii y Shevchuk Hennadii

Mediation in criminal proceedings: legal regulation in Ukraine and foreign experience of application

LAW OF UKRAINE. 2012. Code of Criminal Procedure of Ukraine of April 13, 2012 no. 4651-VI. Available online. In: https://zakon.rada.gov.ua/ laws/show/4651-17\#Text. Date of consultation: 18/09/2020.

MARKOVICHEVA, Elena 2009. "The role of the institution of mediation in accelerating of trial proceedings" In: Russian judge. Vol. 1, No. 9. pp. 2628.

NESTOR, Nataliia. 2014. "Mediation in the criminal process of the United Kingdom of Great Britain" In: Bulletin of the Ministry of Justice of Ukraine. Vol. 10, No. 12, pp. 144-148.

PLENUM OF THE SUPREME COURT OF UKRAINE. 2004. Resolution "On the practice of application of legislation in cases of juvenile delinquency by the courts of Ukraine" of April 16, 2004, no. 5. Available online. In: https://zakon.rada.gov.ua/laws/show/va005700-04\#Text. Date of consultation: 18/09/2020.

PROSECUTOR GENERAL OF UKRAINE. 2008. Letter "On the use of mediation in criminal proceedings and the expansion of alternatives to prosecution" of August 01, 2008 no. 09 / 1-233vyh-08-236okv. Available online. In: https://issuu.com/uccg/docs/31_rekomend_genprokur_ zastosuvan_mediaciyi_jano9. Date of consultation: 18/09/2020.

SHAPLAND, Joanna et al. 2004. "Implementing restorative justice schemes (CrimeReduction Programme): a reporton thefirstyear”.In:HomeOffice. Available online. In: https://restorativejustice.org.uk/sites/default/ files/resources/files/Ministry\%200f\%20Justice\%20Evaluation\%20 Implementing\%20restorative\%20justice\%20schemes\%20(Crime\%20 Reduction\%20Programme)\%20The\%20first\%20year\%2oreport.pdf. Date of consultation: 18/09/2020.

SUFIYAROVA, Rimma and MANSUROV, Timur. 2018. "Specificity and techniques for resolution of gender conflicts in migrants and host community in public catering organizations of the Republic of Tatarstan" In: Amazonia Investiga. Vol. 7, No. 15.

THE EUROPEAN FORUM FOR VICTIM-OFFENDER MEDIATION AND RESTORATIVE JUSTICE. 2000. Victim-Offender Mediation in Europe. Making Restorative Justice Work. In: Leuven University Press. Leuven, Belgium.

THE EUROPEAN PARLIAMENT AND THE COUNCIL OF THE EUROPEAN UNION. 2008. Directive 2008/52/EC on certain aspects of mediation in civiland commercial matters of 21 May 2008. Available online. In: https:// eur-lex.europa.eu/legal-content/EN/TXT/?uri=celex:32008Lo052. Date of consultation: 18/09/2020. 
TRENCZEK, Thomas. 2001. "Victim-Offender Mediation in Germany - ADR Under the Shadow of the Criminal Law?” In: Bond Law Review, Vol. 13, No. 2, pp. 1-17.

TUMANIANTS, Anush. 2009. "Introduction of the institute of mediation into criminal justice of Ukraine” In: Problems of legality, Vol. 12, N. 101, pp. 139-146.

UNITED NATIONSCOMMISSION ON INTERNATIONALTRADE LAW. 2019. United Nations Convention on International Settlement Agreements Resulting from Mediation of 20 December 2018 [on the report of the Sixth Committee (A/73/496)] 73/198. Availablejijj online. In: https:// uncitral.un.org/sites/uncitral.un.org/files/singapore_convention_eng. pdf. Date of consultation: 18/09/2020.

VINOGRADOVA, Oksana. 2003. "Problems of introduction of the institute of mediation. Information server of the Supreme Court of Ukraine". In Viaduct-Telecom. Kiev, Ukraine.

ZEMLIANSKA, Valentyna. 2008. "Restorative justice in the criminal procedure of Ukraine: a guide”. In: Publisher Zakharenko, V. O. Kyiv, Ukraine.

ZHMUD, Viktoriia. 2008. "Introduction of mediation procedure in Ukrainian legislation” In: Yustynian, Issue 4, Num. 6, pp. 13-14. Available online. https://minjust.gov.ua/m/str_11347. Date of consultation:18/o9/2020. 

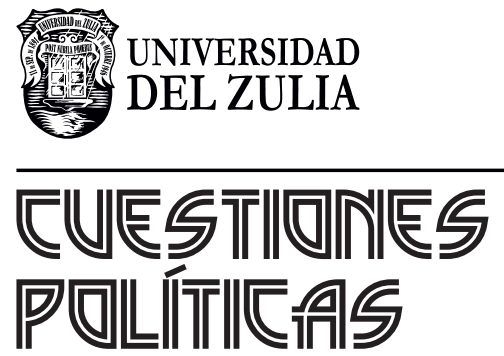

Vol.38 NEspecial

Esta revista fue editada en formato digital y publicada en diciembre de 2020, por el Fondo Editorial Serbiluz, Universidad del Zulia. Maracaibo-Venezuela 